\title{
Sharia Compliance on Murabaha Financing
}

\author{
Elis Mediawati, Silviana Agustami \\ Accounting Departement \\ Universitas Pendidikan Indonesia \\ Bandung, Indonesia \\ elis.mediawati@upi.edu
}

\begin{abstract}
This research aims to find out how the sharia compliance supervision on murabaha financing, as well as things become supporters and obstacles in fulfillment of sharia principles on murabaha financing at BMT. This study used a qualitative descriptive method. The data used is Primary data were obtained from interviews. Determination of data sources using purposive sampling method by interviewing people who were directly involved in the practice as well as the supervision of murabaha financing. Mechanical testing of the credibility of the data using triangulation theory and triangulation source. Monitoring compliance with sharia on murabaha financing is more focused on the Sharia Supervisory Board (SSB), but oversight has not done optimally. As for the supporting fulfillment of sharia principles among which the active role of SSB, and the training given to employees about Islamic principles, while obstacles in fulfillment of sharia is the understanding and awareness of the BMT and the client is still low for implementing murabaha financing that is true to the principles of Islam.
\end{abstract}

Keywords-Shariah Compliance, Murabaha, Baitul Maal Wa tamwil, sharia supervisory board, Islam

\section{INTRODUCTION}

Baitul Maal Wat Tamwil (BMT) or Center for Independent business Integrated is a microfinance institution that has been operated by the principle of sharing, grow and develop the business venture micro in order to elevate, dignity and defend the interests of the poor [1]. In addition to Islamic principles that became the basis of fundamentals, excellence BMT in operations carried out by way of mentoring to its members so that this approach gave rise to a very high level of confidence to members.

Adiwarman Karim said standardization BMT carried out on three major aspects of the standard operating procedures (SOP), human resources (HR) and financial statements. From the SOP, the services provided by BMT must meet specified qualification. Then to HR, it is necessary certifications so that customers served by the human resources with skills and the competencies that have been certified. Finally in terms of the financial statements, shall be audited, and they also must have SSB [2].

Regarding the monitoring of compliance with sharia, DSNMUI has appointed Sharia Supervisory Board (SSB) in each Islamic Financial Institutions (IFIs) as representing DSN MUI to supervise and ensure that the IFIs has been operating according to Islamic principles. But in fact the presence of SSB in every IFIs does not make people feel satisfied because people still see the gap between theory and practice.

The role of sharia SSB is still is optimal [3]. Though SSB is an independent institution whose main function is to supervise compliance with the sharia in the operations of IFIs. IFIs need to be aware when they often overlook compliance Islamic principles, they will face the risk of reputation leads to damage the image off IFIs themselves. Research on BMT Yogyakarta found that BMT in general has implemented internal control, but there are still weaknesses in the authorization procedures and the presence of SSB, from 19 samples only 11 BMT has SSB [4]

To ensure Islamic financial institutions in accordance with sharia, each agency must have a SSB [5][6](Karim, 1990; Briston and El-Ashker, 1986), SSB also involved in accounting policies and reporting shari'a could be justified on the basis that the report may convince the reader that the financial statements are in accordance Islamic law [5].

Islamic financial institutions have the SSB who has knowledge of the financial and sharia, so the SSB can help management develop products according to sharia [7]. SSB has three functions: sharia certification of products and operations, oversight and guidance function [8]. In carrying out its functions independence of SSB is very important for users of financial statements [5]

\section{LITERATURE REVIEW}

BMT is a business organization that also play a social function and role of the BMT as follows: As an investment manager, to play its role as an agent or as a liaison for the owners of the funds; As an investor, if the source of the funds obtained from members or loans from other parties are then managed in professional and effective without the special requirements of the owner of the fund; Social function, providing better social services to members and dhua'fa.

Shari'ah audit is the examination of an Islamic Financial Instititions (IFI's) compliance with the shari'ah. In all its activities particularly subject to the financial statements and other operational components of the IFI that are subjected to the risk of compliance including but not limited to products, the technology supporting the operations, operational process, the people Involved in key areas of risk, documentations and contracts, policies and procedures and other activities that require adherence to sharia principles [9]. Supervision of the sharia compliance in IFIs carried out by the Sharia Supervisory 
Board (SSB). SSB is an independent body that was placed by the National Sharia Council (DSN) on the Islamic financial institution whose members consist of experts muamalah and finance [10].

Rosly suggests four approaches a parameter in sharia compliance. Such approaches are interrelated, namely: the goal of sharia (maqasid shariah) approach, the contract approach, financial reporting approach and legal documentation approach. So it is important for SSB to recognize the role of legal documentation and financial reporting arising from the products which they approved [11].

AAOIFI standards explicitly stated SSB is intended to investigate the suitability of Islamic banks with the principles and rules of Sharia in all its activities. Investigations including examinations of memorandum, contracts, financial reports and other reports [12].

\section{RESEARCH METHOD}

Research was conducted in BMT in Bandung, using qualitative description. The data used is primary data were obtained from interviews. Determination of data sources using purposive sampling method by interviewing people who were directly involved in the practice as well as the supervision of murabaha financing. Mechanical testing of the credibility of the data using triangulation of theory and triangulation of sources.

\section{RESULT AND DISCUSSION}

Sharia supervision on murabaha financing to obtain reasonable assurance that: Funding is based on the principle of murabaha; Murabaha based on the DSN MUI fatwa ; Discount is not intended to adjust the interest rates [13]

Substantive tests on murabaha transactions should be done by SSB include: Ensuring traded goods are not prohibited by Islamic law; Ensuring selling price and margin ;Examining whether wakalah been made separately from murabahah contract [13]

SSB BMT conduct supervision as follows: SSB came to the head office; SSB requesting the data needed to conduct surveillance; Examining the contract based on sharia law ;Prepare the examination report; If there is any divergence findings with the rules, will be penalized as a strike and will be communicated to the supervisor.

The findings of the sharia supervision are: There are murabahah and wakalah contract at the same time;Traded goods as the collateral murabaha contract.

Supporting factor in the fulfillment of sharia principles among which the active role of SSB, and the training given to employees about Islamic principles, while obstacles in fulfillment of sharia is the understanding and awareness of the BMT and customers who are still low to apply murabaha financing according to the Islamic principle.

\section{CONCLUSIONS}

Supervisor over sharia compliance on murabaha financing is more focused on the Sharia Supervisory Board (SSB), but oversight has not done optimally. As for the supporting fulfillment of sharia principles among which the active role of $\mathrm{SSB}$, and the training given to employees about Islamic principles, while obstacles in fulfillment of sharia is the understanding and awareness of the BMT and the client is still low for implementing murabaha financing that is true to the principles of Islam.

\section{REFERENCES}

[1] Amin,Azis 2008, Tata cara Pendirian BMT, Jakarta: pkes publishing

[2] www.ekonomisyariah.info)

[3] Agustianto. 2008. Optimalisasi Peran Dewan Pengawas Syariah. www.niriah.com

[4] Sartini, Wardiwiyono.(2012) Internal control system for islamic micro financing: an exploratory study of baitul maal wat tamwil in the city of Jogjakarta Indonesia. International Journal of Islamic and Middle Eastern Finance and Management. Vol. 5 No. 4,. 340-35

[5] Karim,R,A,A,. 1990. Independence of religious and external auditors : the case of islamic banks. Auditing, accounting and accountibility journal, vol 3, No.3, $33-44$.

[6] Briston and El Ashker. 1984. Religious audit coud it happen here? . Accountancy. October 120

[7] Ghayad, Racha. 2008. Corporate Governance and the global performance of islamic bank. Humanomics Vol 24 No 3, $207-216$

[8] Casper, Mathias. 2012. Sharia boards and sharia compliance in the eropean corporate governance. http://ssrn.com/abstract=2179412

[9] Syed, Alwi Mohamed Sultan, (2009). Shariah Audit for Islamic Financial Institutions-A Primer . Kuala Lumpur: Cert Publicatios. www.ekonomisyariah.info

[10] Adiwarman A Karim,. (2010). Bank Islam, Analisis Fiqih dan Keuangan. Edisi Keempat. Jakarta: PT RajaGrafindo Persada .

[11] Rosly, Saiful Azhar. Shariah parameters considered. International Journal of Islamic and Middle Eastern Finance and Management. Vol. 3 No. 2, 132 - 146

[12] Bakar, M.D,. 2002. The sharia supervisory board an issue of sharia rules and harmonisation in Islamic banking and finance, dalam Islamic Finance Innovation and growth (editor) S.Archer and R.A.A. Karim , economy books and AAOIFI. London. $74-89$

[13] Muhamad. 2011. Audit dan Pengawasan Syariah pada Bank Syariah. Yogyakarta : UII Press 